Matematikai Közlemények

VIII. kötet, 2020

doi:10.20312/dim.2020.05

\title{
Havi átlaghőmérsékletek regressziós vizsgálata
}

\author{
Csanády Viktória \\ SOE Matematikai Intézet \\ csanady.viktoria@uni-sopron.hu
}

\begin{abstract}
ÖSSZEFOGLALÓ. A klímaváltozás napjaink egyik fontos kutatási témája. A felmelegedés, a hőmérséklet emelkedés már kimutatott tény, számtalan tudományos publikáció jelenik meg e témában. Felmerül a kérdés azonban, hogy csupán az átlaghőmérsékletekkel, mint jellemző értékekkel mit kezdhetünk, milyen információt birtokolnak és abból vagy azokból milyen következtetést vagy következtetéseket vonhatunk le.

Az alábbiakban több mint 100 év átlaghőmérsékleti adatai közül 5 éves periódusban kiválasztott évek havi középhőmérsékletei adják a vizsgálat tárgyát, a módszer pedig regressziós vizsgálat két alkalmas modell felhasználásával.
\end{abstract}

\begin{abstract}
Climate change is an important research topic nowadays. Global warming and temperature rise have been proved and described in several scientific publications. The questions arise: for what can we use the average temperature as a specific data; what kind of information does it carry; and what kind of conclusions can be drawn from it.

In the followings, we examine the average monthly temperatures in chosen periods of five consecutive years from more than a hundred years' data. We apply two suitable regression models for our investigations.
\end{abstract}

\section{Bevezetés}

Napi aktualitással kapjuk az információt időjárásunk legfontosabb jellemzőiről, amit természetesen csak aktualitásában használunk leggyakrabban fel, a szélsőségek azonban mindenki számára ismertek. Ha azonban csak egy átlaghőmérséklet áll rendelkezésünkre, vajon milyen következtetést vonhatunk le. Nyilván az átlag elrejti a szélsőségeket, de hosszú távon jeleznie kell a már igazolt hőmérséklet emelkedést, illetve jeleznie kell a hőmérsékleti tendencia változását.

\section{Anyag és módszer}

A vizsgálat tárgyát 118 esztendőből 5 évenkénti periódusban vételezett évek adják, nevezetesen 1901, 1905, 1910, .., 2015 és 2019. évi Budapesten mért havi átlaghőmérsékleti adatokkal reprezentálva. Az éves adatsorok elemzése alkalmas grafikonok révén történik, valamint regressziós elemzés felhasználásával melynek során két modell illesztésére kerül sor. Az alábbi táblázatokban olvashatók a vizsgált adatok, szemrevételezhetők a differenciák. 


\begin{tabular}{|l|l|l|l|l|l|l|l|l|}
\hline \multicolumn{10}{|c|}{ Havi átlagmőmérséklet } \\
\hline & 1901 & 1905 & 1910 & 1915 & 1920 & 1925 & 1930 & 1935 \\
\hline Január & $-4,7$ & $-3,2$ & 1,5 & 2,1 & 3,1 & 0,2 & 0,3 & $-2,2$ \\
\hline Február & $-2,1$ & 1,8 & 5,3 & 2 & 2,3 & 5,6 & 1,4 & 0,6 \\
\hline Március & 5,8 & 7,1 & 7,4 & 3,5 & 8,2 & 5,1 & 7,6 & 4,6 \\
\hline Április & 11,6 & 9,5 & 10,9 & 10,8 & 14,2 & 11,3 & 12,4 & 11,1 \\
\hline Május & 16,8 & 16,4 & 16 & 16,9 & 18,5 & 17,7 & 15,6 & 14,9 \\
\hline Június & 21 & 20,4 & 19,9 & 20,3 & 17,8 & 18 & 21,8 & 21,7 \\
\hline Július & 22,4 & 23,7 & 20,3 & 20,1 & 21,8 & 21,2 & 21,6 & 21,9 \\
\hline Szeptember & 20,7 & 22,4 & 20,1 & 18,3 & 18,8 & 20,3 & 20,2 & 20,2 \\
\hline Október & 15,9 & 18 & 14,4 & 13,4 & 16,1 & 14,5 & 17,9 & 16,2 \\
\hline November & 12,6 & 7 & 10,1 & 9,5 & 7,9 & 11,3 & 11,3 & 13,7 \\
\hline December & 4,7 & 6,7 & 3,8 & 3,2 & 0,4 & 5,8 & 7,7 & 4,8 \\
\hline
\end{tabular}

1. táblázat. Havi átlaghőmérséklet 1901-2035

\begin{tabular}{|l|l|l|l|l|l|l|l|l|}
\hline \multicolumn{10}{|c|}{ Havi átlagmőmérséklet } \\
\hline & 1940 & 1945 & 1950 & 1955 & 1960 & 1965 & 1970 & 1975 \\
\hline Január & -7 & $-3,5$ & $-2,3$ & -1 & $-1,2$ & 0,7 & $-1,2$ & 3,3 \\
\hline Február & -5 & 1,9 & 1,8 & 1,2 & 0,3 & $-1,6$ & 0,6 & 2,1 \\
\hline Március & 2,6 & 6,7 & 8,1 & 4,4 & 6,9 & 5,9 & 4,8 & 8,7 \\
\hline Április & 11,5 & 12,2 & 12,3 & 8,7 & 11,4 & 10 & 11 & 11,4 \\
\hline Május & 14,4 & 18,2 & 18,7 & 15,1 & 15,6 & 14,7 & 15 & 18,4 \\
\hline Június & 19,3 & 20,9 & 21,7 & 19,1 & 20,3 & 19,1 & 20,6 & 19,5 \\
\hline Július & 20,7 & 22,4 & 24,2 & 21 & 19,7 & 20,6 & 20,9 & 21,6 \\
\hline Szeptember & 17,7 & 21,2 & 22,5 & 19,6 & 20,8 & 18,8 & 20,5 & 20,8 \\
\hline Október & 16,1 & 17 & 17,4 & 16,8 & 15,6 & 16,7 & 16,3 & 18,7 \\
\hline November & 10,8 & 10,5 & 9,7 & 10,9 & 12,3 & 9,9 & 10,5 & 11,3 \\
\hline December & 8,1 & 5,5 & 6,1 & 5,6 & 8 & 2,9 & 8,3 & 4,4 \\
\hline
\end{tabular}

2. táblázat. Havi átlaghőmérséklet 1940-2075

\begin{tabular}{|l|l|l|l|l|l|l|l|l|l|}
\hline \multicolumn{10}{|c|}{ Havi átlagmőmérséklet } \\
\hline & 1980 & 1985 & 1990 & 1995 & 2000 & 2005 & 2010 & 2015 & 2019 \\
\hline Január & $-2,5$ & $-3,9$ & 1 & 0,2 & $-0,7$ & 1,4 & -1 & 3 & 1,1 \\
\hline Február & 2,5 & -3 & 6,3 & 6,3 & 4,6 & $-1,2$ & 1,6 & 3,6 & 5,9 \\
\hline Március & 5,6 & 5,5 & 10,3 & 5,6 & 6,8 & 4,7 & 7,1 & 8,2 & 10,5 \\
\hline Április & 9,2 & 11,8 & 11,1 & 11,8 & 14,8 & 12,2 & 12,8 & 12,7 & 14,4 \\
\hline Május & 14,3 & 17,4 & 17,8 & 15,8 & 18,5 & 17,1 & 16,6 & 17,3 & 15 \\
\hline Június & 18,7 & 17,1 & 19,3 & 19 & 21,7 & 19,7 & 20,5 & 21,6 & 24,9 \\
\hline Július & 19,8 & 21,7 & 21,3 & 24,9 & 20,3 & 21,7 & 23,9 & 25,1 & 23,6 \\
\hline Szeptember & 20,3 & 21,5 & 22,5 & 20,9 & 23,8 & 19,7 & 21,5 & 24,9 & 24,7 \\
\hline Október & 15,7 & 17,2 & 15 & 15,2 & 16,2 & 17,6 & 15,3 & 18,4 & 18,7 \\
\hline November & 11,2 & 10,8 & 11,1 & 12,6 & 14,2 & 12 & 9,4 & 11,3 & 14,7 \\
\hline December & 4,3 & 4,4 & 6,6 & 3,3 & 9 & 4,8 & 9,4 & 8,6 & 10 \\
\hline
\end{tabular}




\section{Számított eredmények, kiértékelés}

A rendelkezésre álló adatok táblázatos elemzése felületes és nem ad kellő információt, ezért első lépésben célszerü az adatok vizuális megjelenítése. Ennek két látványos lehetősége is adott, elsőként tekintsük független változónak a hónapokat és függőnek a havi átlaghőmérsékleteket, így a vizsgált évek hőmérsékletváltozási tendenciái jól láthatók, ahogy azt az alábbi ábrák is mutatják var3=1901,var4=1905, .., var27=2019.

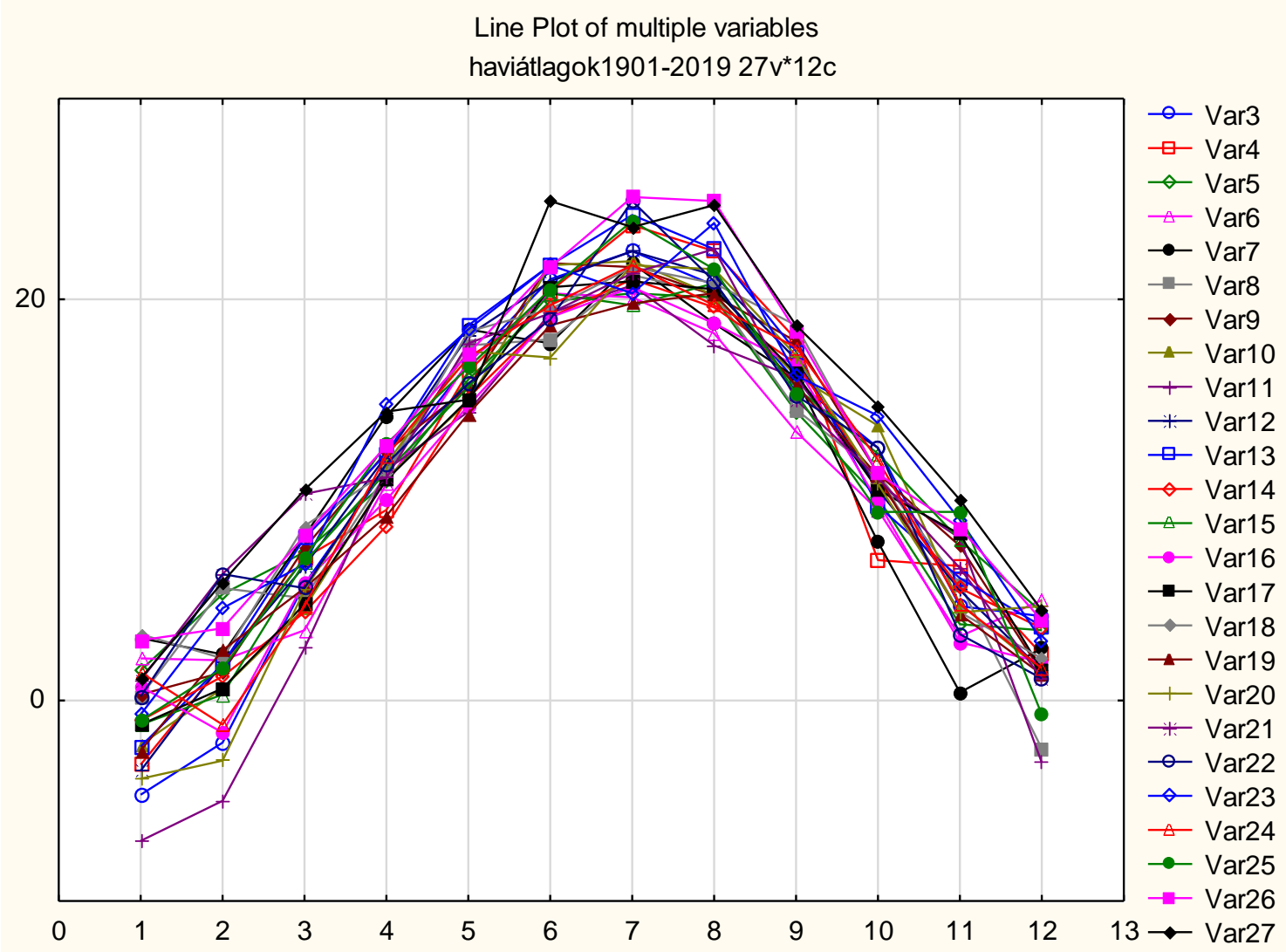

1. ábra. Havi átlaghőmérsékletek

Egy másik lehetőség az egyes hónapok hőmérsékleteinek vizsgálata az évek függvényében, itt tehát a független változó a vizsgált 25 év ahol var3=1901, var4=1905, ..., var27=2019, a függő változó pedig egy adott hónap átlaghőmérséklete 12 hónapra kibővítve. Az alábbi ábrán nyomon követhetjük tehát az egyes évek változásait ahol case $1=$ a januári középhőmérséklet case $2=$ a februári középhőmérséklet és így tovább case12= a decemberi középhőmérséklet. Az ábra jól szemlélteti az egyes évek kiugró változását egy-egy adott hónapra nézve, míg az előző ábra a havi középhőmérsékletek trendjét jelzi. Mind a két ábra azonban csak tájékoztató jellegü, matematikai vagy statisztikai mutató nélkül. 


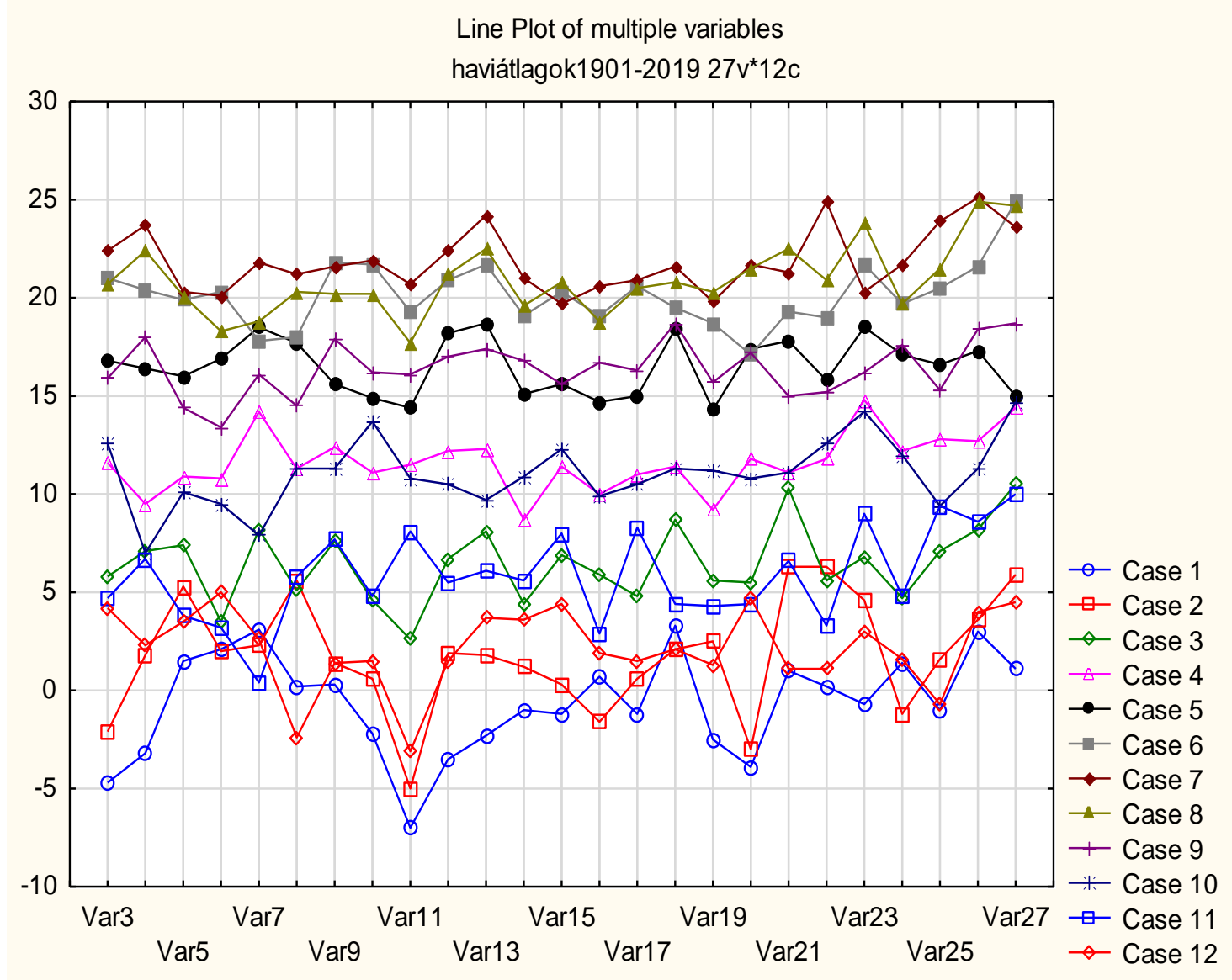

2. ábra. Havi átlaghőmérséklet évenkénti változása

A vizuális vizsgálat 1 . ábrája instrukciót ad a regressziós vizsgálat modellválasztására . A rendelkezésre álló adatok jellegének áttekintése alapján a kiválasztandó függvénynek rendelkeznie kell maximummal, a közelítő szimmetria miatt két inflexiós ponttal, és szükséges, hogy felülről és alulról is korlátos legyen. Ezen túlmenően paraméterei legyenek közvetlenül értelmezhetők, és darabszámuk minél több közvetlen vagy közvetett információt adjon.

Mind ezek figyelembevételével két modell alkalmazására került sor, elsőként egy Gauss-görbére, majd pedig egy szinuszawrami illesztésére. Az alkalmazott két modell számítógépes alakja:

1. $\operatorname{var} 2=b 3 / \exp \left(b 2 *(\operatorname{var} 1-1 * b 1)^{\wedge} 2\right)+b 0$

A függvény görbületi jellege állandó a 2 -es hatványkitevő miatt.

2. $\operatorname{var} 2=b 3 * \sin (3.14159 *(1-\exp (-1 *(b 2 * \operatorname{var} 2) \wedge b 1)))+b 0$

A függvény nem periódikus, nem szükségszerüen szimmetrikus, egy maximummal rendelkezik valamint egy vagy két inflexiós ponttal.

A kétszer 25 illesztés paramétereinek értékei, az alábbiakban nem kerülnek felsorolásra, viszont az alábbi táblázat tartalmazza az illesztések jóságát igazoló nem lineáris korrelációs együttható (korrelációs index) értékeit. 


\begin{tabular}{|c|c|c|c|}
\hline Évek & $\mathrm{R}$ - gauss görbe esetén & $\mathrm{R}$ - szinuszawrami esetén & deltaR \\
\hline 1901 & 0,9882 & 0,9939 & 0,0057 \\
\hline 1905 & 0,9825 & 0,9803 & $-0,0022$ \\
\hline 1910 & 0,9916 & 0,9863 & $-0,0053$ \\
\hline 1915 & 0,9829 & 0,9862 & 0,0033 \\
\hline 1920 & 0,9677 & 0,9557 & $-0,012$ \\
\hline 1925 & 0,9736 & 0,9573 & $-0,0163$ \\
\hline 1930 & 0,9931 & 0,9866 & $-0,0065$ \\
\hline 1935 & 0,9933 & 0,9899 & $-0,0034$ \\
\hline 1940 & 0,9868 & 0,9813 & $-0,0055$ \\
\hline 1945 & 0,9982 & 0,9934 & $-0,0048$ \\
\hline 1950 & 0,9925 & 0,9924 & $-0,0001$ \\
\hline 1955 & 0,9975 & 0,9978 & 0,0003 \\
\hline 1960 & 0,9923 & 0,9942 & 0,0019 \\
\hline 1965 & 0,9861 & 0,9828 & $-0,0033$ \\
\hline 1970 & 0,9944 & 0,9932 & $-0,0012$ \\
\hline 1975 & 0,9812 & 0,9713 & $-0,0099$ \\
\hline 1980 & 0,9941 & 0,9862 & $-0,0079$ \\
\hline 1985 & 0,9773 & 0,9807 & 0,0034 \\
\hline 1990 & 0,9784 & 0,9611 & $-0,0173$ \\
\hline 1995 & 0,9743 & 0,9676 & $-0,0067$ \\
\hline 2000 & 0,9849 & 0,9772 & $-0,0077$ \\
\hline 2005 & 0,9854 & 0,9825 & $-0,0029$ \\
\hline 2010 & 0,9833 & 0,9777 & $-0,0056$ \\
\hline 2015 & 0,9937 & 0,9915 & $-0,0022$ \\
\hline 2019 & 0,9789 & 0,9705 & $-0,0084$ \\
\hline
\end{tabular}

4. táblázat. Korreláció együttható (korrelációs index) értékei

A fenti táblázatból kitünik, hogy a legkisebb R érték 0,9557 ami jó illeszkedésre utal, a többi esetben az értékek ennél még magasabbak, így a két modell szorosan követi a pontsorozat tendenciáját. Az R értékek eltérése elenyésző legszélsőségesebb esetben is csak 0,0173, ami azt igazolja, hogy mindkét modell alkalmas a trend leírására.

Megjegyzendő, hogy a modellek illesztése során a kezdőértékek megadása nem okoz problémát. A Gauss-görbe esetén a kezdőértékek közül csak a vízszintes eltolási paraméter igényel korrigálást a program által megadott alapértékekre vonatkozóan, ami a pontsorozat maximumának helyével egyezik. Három esetben pedig a függőleges nyújtási paraméter értéke szorult korrekcióra a gép által megadott 0,1 helyett 1-re a pontsorozat hirtelen meredeksége miatt.

A szinuszawrami esetén a kezdőértékek nem szorultak korrekcióra, a program eredeti kezdőértékei alkalmasak a program futtatása során.

Az alábbi két ábra az illesztett két modell görbeseregét mutatja, melyek jelentős formai eltérést nem mutatnak. A Gauss-görbék esetén nagyjából paralel a lefutás, csak az 1940-es év kritikus, melynek során a hőmérséklet emelkedése kezdetben szinte lineáris és ez jellemzi az év utolsó hónapjait is nyilván közel lineáris csökkenéssel. A többi esetben lényegesen kisebb a formai eltérés ami vízszintes és függőleges eltolódásból adódik föként. A maximum értékek legnagyobb eltérése 4,8 Celsius fok, ami az illesztés esetén is teljesül.

A szinuszawrami illesztése során kapott görbesereg a modell rugalmassága miatt már nem szimmetrikus, az egyes évek trendje legtöbb esetben paralel. A maximum értékek legnagyobb eltérése itt is megfelel az adatokból kapott 4,8 Celsius fok értéknek 


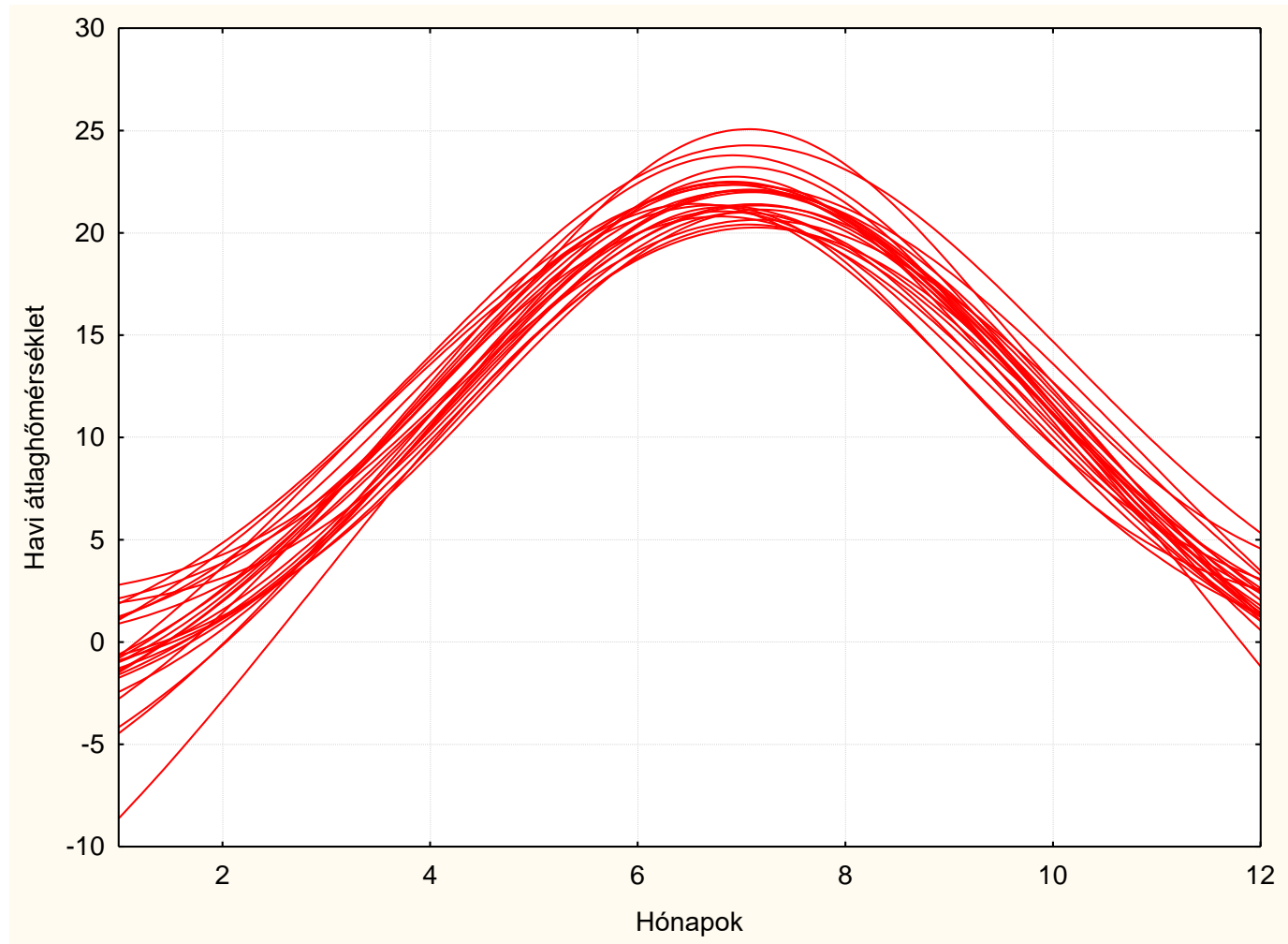

3. ábra. Görbesereg Gauss-görbe esetén

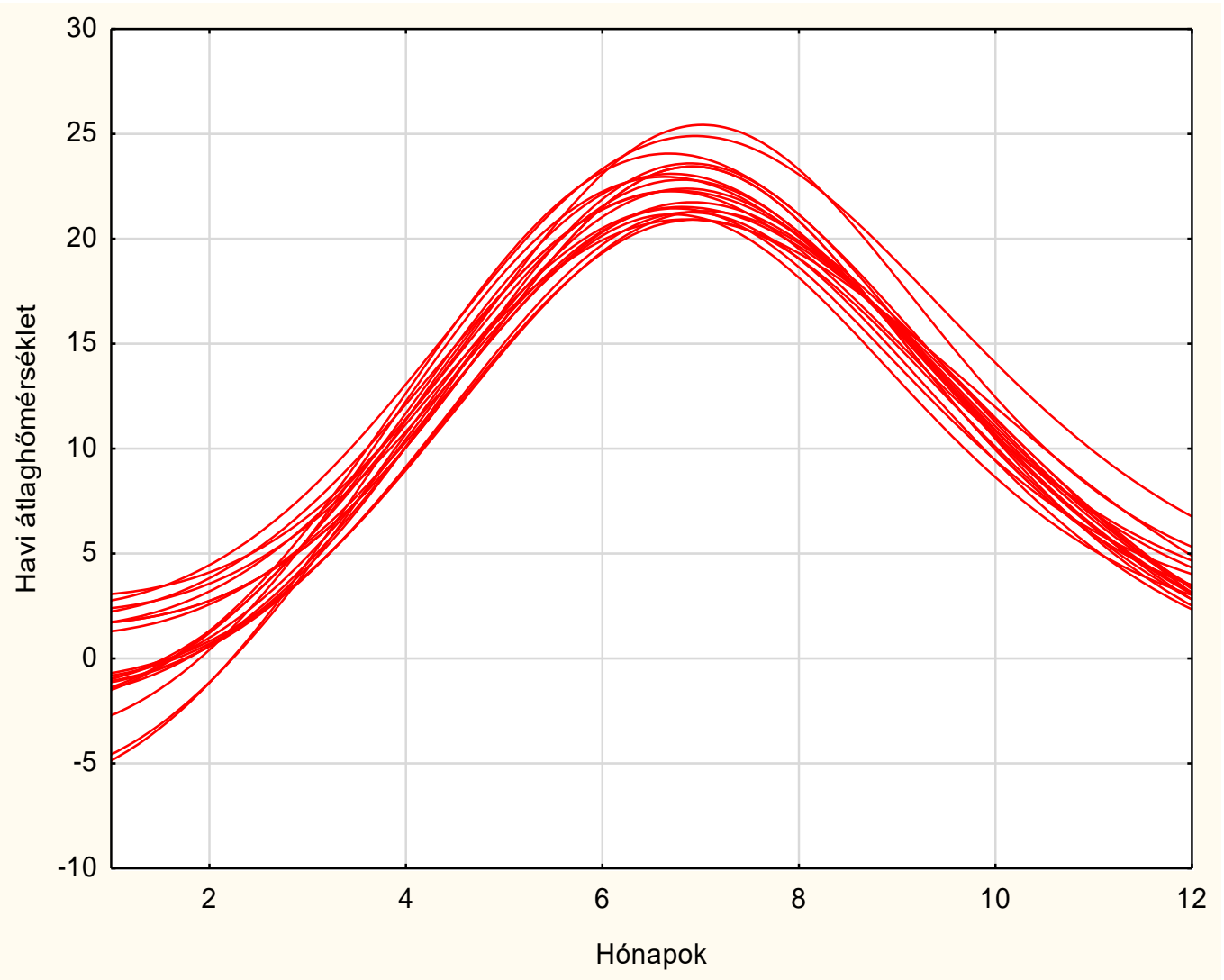

4. ábra. Görbesereg szinuszawrami esetén 


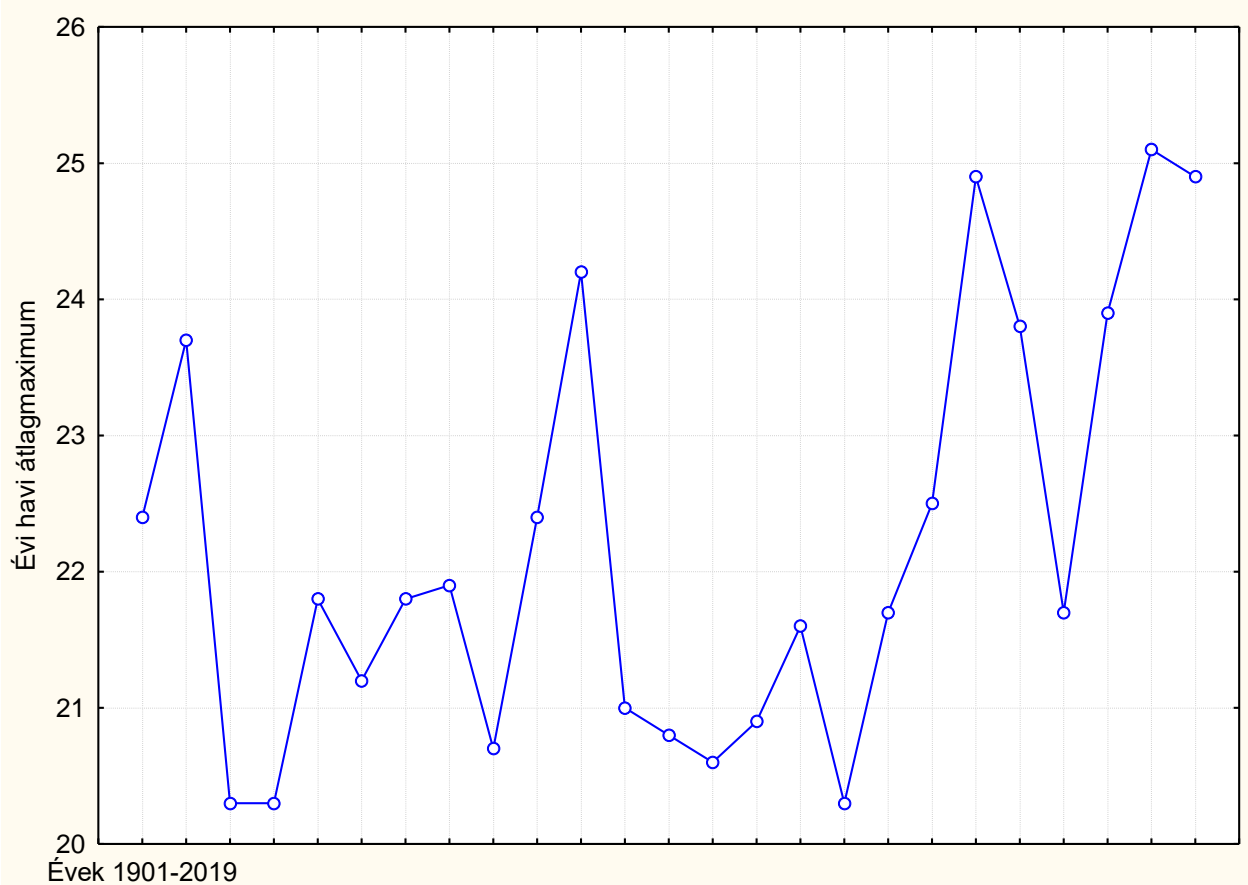

5. ábra. Évenkénti havi átlagmaximumok

A 3.5 ábra az évenként előforduló legmagasabb havi középhőmérsékletet mutatja az adott évhez tartozóan. Az adatok ingadozásának mértéke nagy a trend viszont emelkedő jellegü.

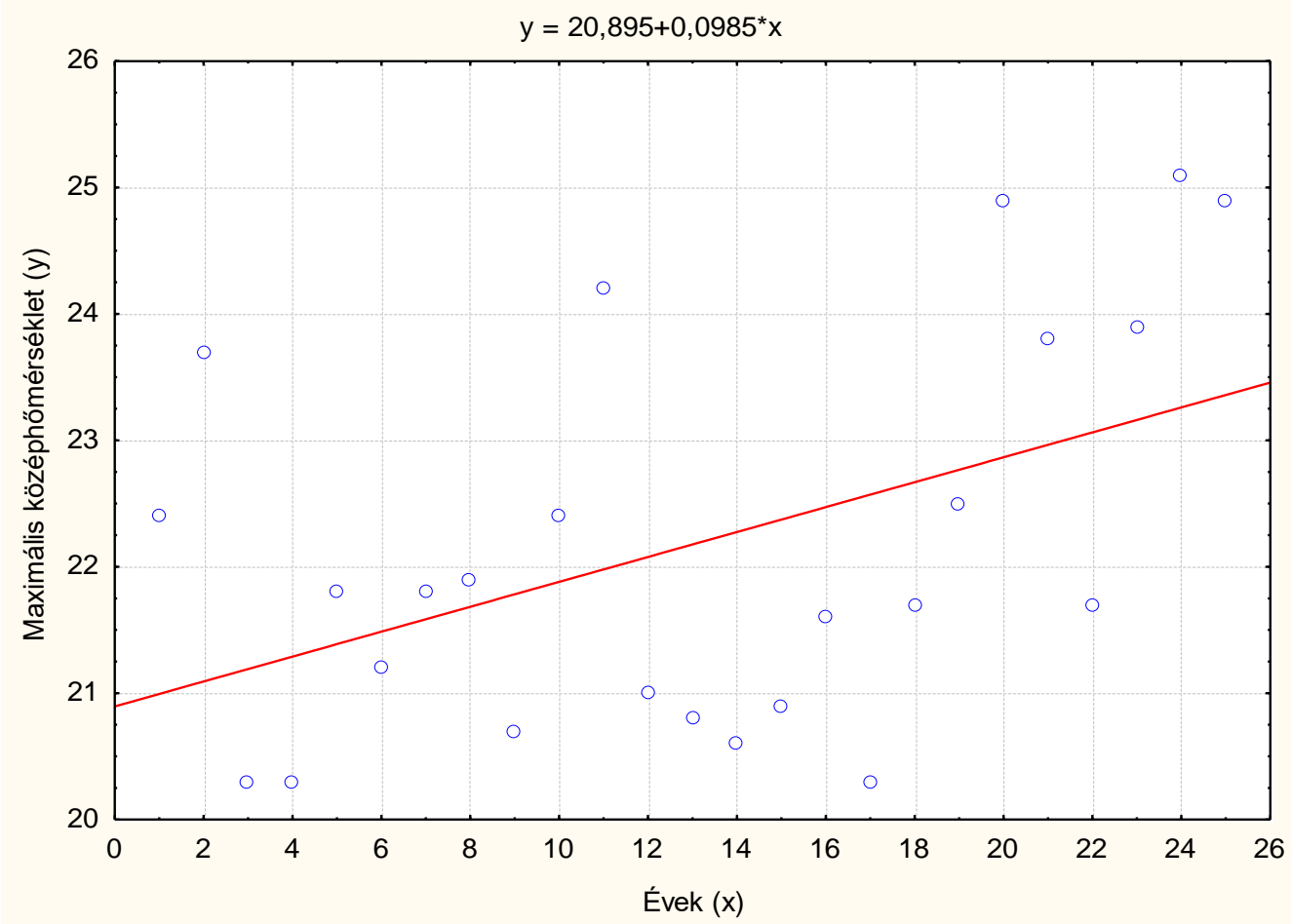

6. ábra. Maximális középhőmérsékletek trendje 
Feltevődik azonban a kérdés, hogy elegendő-e csupán a havi középhömérsékletek vizsgálata ahhoz, hogy teljes részletes képet adhassunk a hőmérséklet alakulásáról. Természetesen nem, mivel a havi középhőmérséklet takarja a havi adatok szélsőséges változását amit az alábbi ábra jól mutat. Viszont a trendek megadásához elegendő.

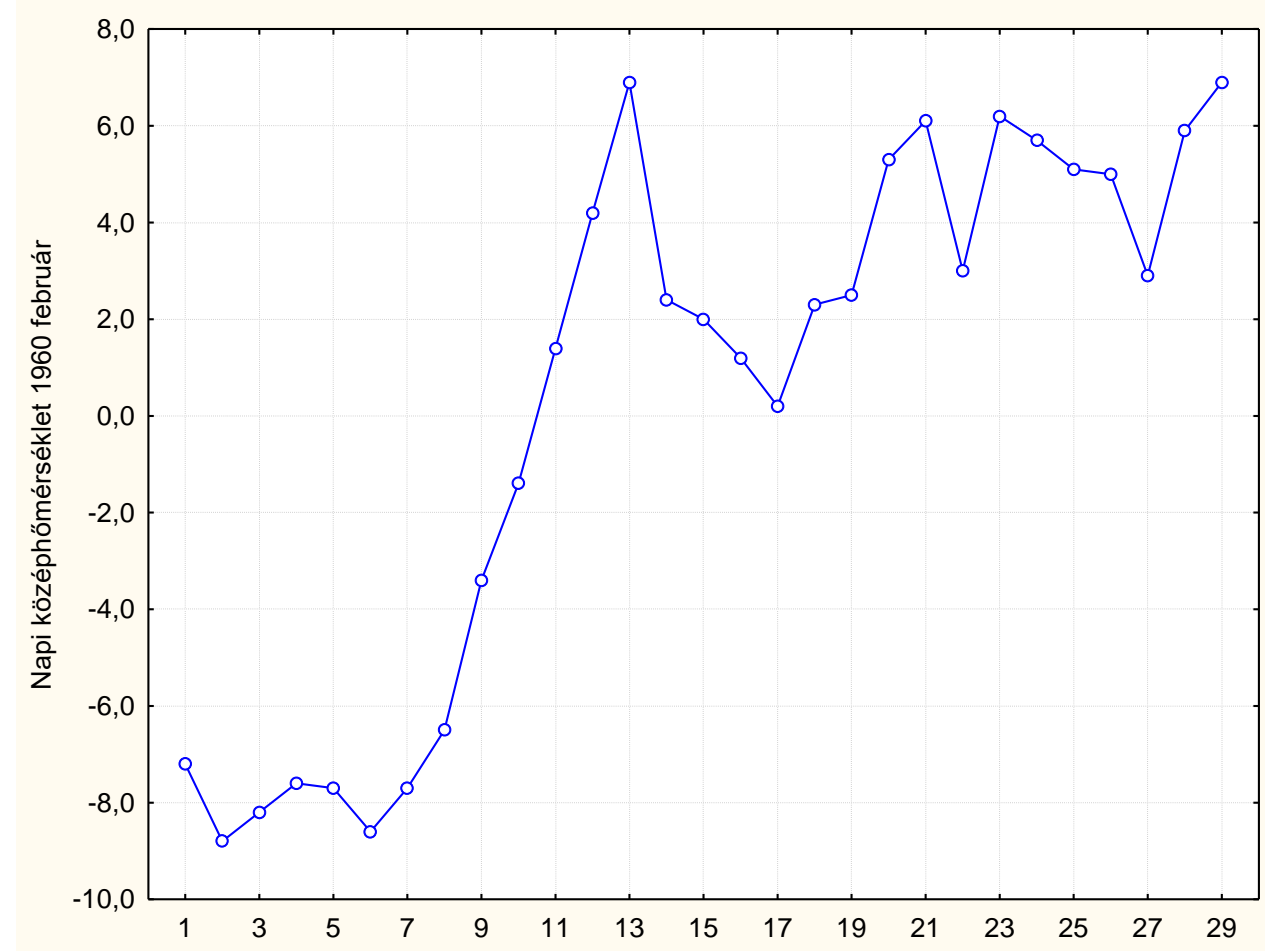

7. ábra. Napi középhőmérsékletek 1960 február

\section{Következtetés}

A vizsgálatokból levonható következtetések szerint elemezve az eredményeket a következő megállapítások tehetők:

- A két modell alkalmas a havi középhömérsékletek tendenciájának vizsgálatára, mely szerint a tendencia nem változik, csak eltolódik.

- A hőmérsékleti maximumok nőnek, trendjük ezt igazolja, a vizsgált időszak a maximum értékekre nézve 5 fok különbséget mutat maximálisan.

- A két modell tendenciájában nem tér el lényegesen szoros korreláció mellett.

- A havi középhőmérsékletek takarják a hőmérsékleti anomáliákat.

\section{5. Összefoglaló}

A felsoroltak és bemutatottak alapján megállapítható, hogy bár a regressziós eljárások alkalmasak a trend bemutatására mégsem adnak biztos eredményt mivel az átlagok kisimítják a hőmérsékleti anomáliákat, így szükséges a napi átlaghőmérséklet beható vizsgálata. 


\section{Irodalomjegyzék}

[1] Csanády V., Horváth-Szováti E., Szalay L., Alkalmazott statisztika, Sopron, Nyugat-Magyarországi Egyetem Kiadó (2013), 175p.

[2] Csanády V., Időjárás elemzés regressziós eljárás alkalmazásával, Dimenziók, Matematikai Közlemények III. (2015), 25-34. doi:10.20312/dim.2015.04

[3] StatSoft Inc., "Statistica," Data Analysis Software System, version 7, 2004. 